\section{IAC OL 5 - New high oleic runner peanut cultivar}

\author{
Ignácio José de Godoy ${ }^{1 *}$, João Francisco dos Santos ${ }^{1}$, Marcos \\ Doniseti Michelotto ${ }^{2}$, Andrea Rocha Almeida de Moraes ${ }^{1}$, \\ Denizart Bolonhezi ${ }^{2}$, Rogério Soares de Freitas ${ }^{1}$, Cassia Regina \\ Limonta de Carvalho ${ }^{1}$, Everton Luis Finoto ${ }^{2}$ and Antonio Lúcio \\ Melo Martins ${ }^{2}$
}

Abstract: IAC OL 5 is a new peanut cultivar recommended to growers of peanut regions of the state of São Paulo as another option for planting during the intervals of sugarcane renewal. Its main traits are its runner growing habit, its moderate resistance to virus and foliar diseases, and the high oleic trait.

Key words: Peanut cultivar, Arachis hypogaea L., runner growing habit, high oleic trait.

\section{INTRODUCTION}

Peanuts are the third most important annual crop, in terms of planting area, of the state of São Paulo, comprising over one hundred thousand hectares (IEA 2016). Most of this area is located in sugarcane cropping regions, where peanuts are planted as a rotation crop.

Currently, peanut production in these areas is highly technified, and uses cultivars of runner growing habit, whose cycle duration varies from 130 to 150 days. Planting peanuts in plots for sugarcane renewal requires that the cycle of the cultivar be no longer than 130 days.

The peanut cultivars that have the high oleic trait (over $70 \%$ of oleic acid in the oil fraction of the seed) are demanded by the peanut industry. Oleic acid content in cultivars that do not have the "high oleic" trait ranges from 40 to $50 \%$. High oleic acid content extends the product's shelf life (Mozingo et al. 2004).

The first high oleic cultivars released in Brazil, IAC 503 and IAC 505, have cycle duration longer than 130 days, from planting to harvesting. This imposes a limitation to their use, due to the requirements in rotation with sugarcane (Godoy et al. 2009). IAC has recently released two other high oleic cultivars, IAC OL3 and IAC OL4 (Godoy et al. 2014), whose cycles do not exceed 130 days, allowing better adjustment to the sugarcane areas. Besides the shorter cycle, these cultivars present high yielding performance at the presence of efficient chemical control of foliar diseases.

IAC OL5 has been released to meet the demand for high oleic runner cultivars, with cycle duration adjusted to the sugarcane rotation system, moderate resistance to virus, and tolerance to foliar diseases.
Crop Breeding and Applied Biotechnology 17: 295-298, 2017 Brazilian Society of Plant Breeding. Printed in Brazil http://dx.doi.org/10.1590/198470332017v17n3c45

(10332017v17n3c45 


\section{BREEDING METHOD}

IAC OL5 was obtained from a cross between the breeding line IAC 23 A - 65/3 and the accession 2562 of the IAC germplasm collection. IAC 23 A - 65/3 is a component line of the cultivar IAC Caiapó, considered moderately resistant to foliar diseases. The accession 2562 was the source of the "high oleic" trait. The $F_{2}$ population was planted in the field and subjected to individual plant selection for yield and pod/seed. From each selected plant, seeds samples $\left(F_{2 \cdot 3}\right.$ progenies) were taken to the laboratory and analyzed by gas chromatography for fatty acid content. Samples showing 70-80\% oleic acid (meaning homozygous recessives for the "high oleic" trait) were selected.

The selected high oleic progenies were subjected to individual plant selection from the $F_{3}$ to $F_{5}$ generation for plant yield and pod/seed physical quality. In the $F_{6}$ generation, individual plant selection was performed based on the degree of seed maturity upon digging the plants at 100 days after planting (early harvesting). In the following 3 years, the best lines of the selected plants were evaluated for yield and seed maturity under anticipated harvesting (digging the plants before 130 days). One of these lines was indicated as the new cultivar IAC OL5.

\section{AGRONOMIC PERFORMANCE}

Cultivar IAC OL5 (tested as line 825) was selected for yield performance out of a group of 15 high oleic lines in 6 experiments carried out in 2 growing seasons (2011/12 and 2012/13), in 3 locations of the state of São Paulo: Ribeirão Preto (lat $21^{\circ} 2^{\prime} \mathrm{S}$, long $47^{\circ} 87^{\prime} \mathrm{W}$, alt $546 \mathrm{~m}$ asl), Pindorama (lat $21^{\circ} 22^{\prime} \mathrm{S}$, long $48^{\circ} 91^{\prime} \mathrm{W}$, alt $527 \mathrm{~m}$ asl), and Votuporanga (lat $20^{\circ} 46^{\prime} \mathrm{S}$, long $50^{\circ} 06^{\prime} \mathrm{W}$, alt $510 \mathrm{~m}$ asl) (Table 1). Plots were harvested between 125 and 130 days after planting, and yield was compared with 3 control cutivars under these conditions, in which the cycle should not exceed 130 days. The new cultivar presented mean of $5.416 \mathrm{~kg} \mathrm{ha}^{-1}$ of unshelled peanuts, and outyielded the control cultivars IAC 503 and IAC 505, whose cycles are longer than 130 days, and the not high oleic IAC 886, whose cycle is of approximately 130 days.

The percentage of mature kernels in the new cultivar was evaluated in the 6 experiments, and the data was compared with the 3 control cultivars (Table 2). On average, cv. IAC OL5 showed maturity close to $80 \%$, indicating that its cycle, from planting to harvesting, is adjusted to the sugarcane rotation, since this situation requires cycles no longer than

Table 1. Yield of peanut lines and cultivars in 6 experiments and 3 locations in the state of São Paulo

\begin{tabular}{|c|c|c|c|c|c|c|c|}
\hline \multirow{3}{*}{ Genotype } & \multicolumn{6}{|c|}{ Experiments $^{1}$} & \multirow{3}{*}{ Mean } \\
\hline & Pindorama & Ribeirão Preto & Votuporanga & Pindorama & Ribeirão Preto & Votuporanga & \\
\hline & \multicolumn{3}{|c|}{$2011 / 12$} & \multicolumn{3}{|c|}{$2012 / 13$} & \\
\hline L. 802 & 4,808 & $3,508 \mathrm{a}$ & $5,328 a$ & 5,534 a & $4,661 \mathrm{~b}$ & 6,351 a & 5,032 \\
\hline L. 807 & 4,890 & $3,146 b$ & $5,683 a$ & $4,383 \mathrm{~b}$ & $4,512 b$ & $5,008 b$ & 4,604 \\
\hline L. 814 & 4,872 & 4,097 a & 5,039 a & 5,446 a & $4,946 b$ & $4,784 b$ & 4,864 \\
\hline L. 815 & 4,864 & 3,802 a & $5,230 \mathrm{a}$ & $5,494 a$ & 5,240 a & $4,907 \mathrm{~b}$ & 4,923 \\
\hline L. 817 & 5,101 & $3,049 b$ & $5,289 a$ & $4,855 \mathrm{~b}$ & $4,401 b$ & $5,024 b$ & 4,620 \\
\hline L. 818 & 4,998 & 3,408 a & $5,741 \mathrm{a}$ & 5,169 a & $5,044 b$ & $5,290 \mathrm{~b}$ & 4,942 \\
\hline L. 821 & 4,858 & 3,933 a & $6,004 \mathrm{a}$ & 6,010 a & $4,702 b$ & 5,444 a & 5,158 \\
\hline L. 823 & 4,846 & 3,719 a & 5,697 a & 6,040 a & $4,857 b$ & 6,228 a & 5,231 \\
\hline L. 824 & 4,763 & 3,476 a & $5,886 a$ & 5,218 a & $4,474 b$ & 5,589 a & 4,901 \\
\hline L. 829 & 4,395 & $3,107 \mathrm{~b}$ & $5,694 \mathrm{a}$ & 5,133 a & $4,702 \mathrm{~b}$ & $5,222 b$ & 4,694 \\
\hline L. 845 & 4,194 & $2,922 b$ & $3,424 b$ & 5,552 a & $4,607 b$ & $4,718 b$ & 4,236 \\
\hline L. 846 & 5,209 & $2,570 \mathrm{~b}$ & $5,430 \mathrm{a}$ & $4,490 \mathrm{~b}$ & 5,816 a & $4,708 \mathrm{~b}$ & 4,704 \\
\hline L. 847 & 5,188 & 3,483 a & 5,295 a & 5,716 a & 5,738 a & $4,200 \mathrm{~b}$ & 4,937 \\
\hline L. 849 & 4,828 & $2,806 \mathrm{~b}$ & $5,776 a$ & $4,504 b$ & $4,141 b$ & 4,978 b & 4,505 \\
\hline IAC OL5 & 5,339 & 4,156 a & 6,119 a & $5,264 a$ & 6,101 a & 5,518 a & 5,417 \\
\hline IAC 503 & 4,966 & $3,028 b$ & $4,292 b$ & $3,730 b$ & $5,280 a$ & $4,845 b$ & 4,357 \\
\hline IAC 505 & 4,527 & 3,676 a & 5,487 a & $4,627 b$ & $4,425 \mathrm{~b}$ & 5,448 a & 4,698 \\
\hline IAC 886 & 4,445 & $3,256 \mathrm{~b}$ & 5,512 a & 5,012 a & $5,133 a$ & $5,220 \mathrm{~b}$ & 4,763 \\
\hline Mean & 4,838 & 3,392 & 5,385 & 5,121 & 4,932 & 5,194 & \\
\hline CV (\%) & 8.7 & 18.3 & 10 & 13.0 & 12.3 & 12.8 & \\
\hline
\end{tabular}

${ }^{1}$ Means followed by the same letter in the column do not significantly differ from each other according to the Tukey's test at $5 \%$ probability. 
130 days. Cultivars IAC 505 and IAC 886 presented maturity values of 74.9 and $74.1 \%$, respectively, and the long cycle CV. IAC 503 presented maturity value of $66.9 \%$.

The growing season of 2015/16 was characterized by an exceptional amount of rain and a high pressure of foliar diseases for the peanut crop, especially late leafspot (Cercosporidium personatum). Under these conditions, yield of CV. IAC OL5 was compared with the recently released high oleic 130 day-cycle cultivars IAC OL 3 and IAC OL4, which are susceptible to the disease, in a three-location experiment (Table 3). The new cultivar had yield ranging from 3.279 to $6.528 \mathrm{~kg} \mathrm{ha}^{-1}$ of unshelled peanuts. IAC OL3 yielded 3.132 to 5.790 , and IAC OL4 yielded 2.510 to $5.877 \mathrm{~kg} \mathrm{ha}^{-1}$. In Ribeirão Preto, the most affected location, IAC OL5 outyielded IAC OL3 by $16 \%$, and IAC OL4, by $45 \%$. These data indicate that IAC OL5 has some tolerance to the disease, when compared with the other two cultivars.

Over the past 3 years, peanut crops in the state of São Paulo have been infected, although in moderate intensity, by viruses of the tospovirus group, TSWV (Tomato Spotted Wilt Virus), and GRSV (Groundnut Ringspot Virus). TSWV is widely spread in the peanut region in the USA, where the virus epidemics are high. The most efficient method of control is varietal resistance. In 2015 and 2016, IAC OL5 was tested for resistance to TSWV in field conditions under high severity of the disease, in Tifton, GA, USA (Table 4). As compared with Tifguard, a highly resistant American cultivar, and Sun Oleic 97, an American standard for susceptibility to the disease, IAC OL5 showed moderate resistance level. Other cultivars commercially known in Brazil, such as Granoleico, IAC OL3, and IAC 886 were classified as susceptible.

Table 2. Percentage of mature kernels in 4 peanut cultivars in experiments harvested between 125 and 130 days after planting

\begin{tabular}{|c|c|c|c|c|c|c|c|}
\hline \multirow{3}{*}{ Genotype } & \multicolumn{6}{|c|}{ Experiments $^{1}$} & \multirow{3}{*}{ Mean } \\
\hline & Pindorama & Ribeirão Preto & Votuporanga & Pindorama & Ribeirão Preto & Votuporanga & \\
\hline & \multicolumn{3}{|c|}{$2011 / 12$} & \multicolumn{3}{|c|}{$2012 / 13$} & \\
\hline IAC OL5 & 81.9 a & $76.6 \mathrm{a}$ & $69.1 \mathrm{a}$ & 80.9 a & $85.7 a$ & $85.4 \mathrm{a}$ & 79.9 \\
\hline IAC 503 & $75.7 \quad \mathrm{c}$ & $62.5 \mathrm{c}$ & $39.5 \mathrm{~b}$ & $66.1 \mathrm{~b}$ & 76.9 a & $80.5 \mathrm{a}$ & 66.9 \\
\hline IAC 505 & $79.1 \mathrm{ab}$ & $73.9 \mathrm{ab}$ & $60.2 \mathrm{a}$ & $78.6 \mathrm{ab}$ & $77.5 \mathrm{a}$ & $80.1 \mathrm{a}$ & 74.9 \\
\hline IAC 886 & $77.2 \mathrm{bc}$ & $68.8 \mathrm{bc}$ & $58.4 \mathrm{ab}$ & $76.4 \mathrm{ab}$ & $82.8 \mathrm{a}$ & $80.8 \mathrm{a}$ & 74.1 \\
\hline Mean & 78.5 & 70.4 & 56.8 & 75.5 & 80.7 & 81.7 & 73.9 \\
\hline CV (\%) & 2.4 & 14.2 & 16.5 & 10.8 & 11.5 & 6.5 & \\
\hline
\end{tabular}

${ }^{1}$ Means followed by the same letter in the column do not significantly differ from each other according to the Tukey's test at $5 \%$ probability.

Table 3. Yield of cv. IAC OL5 compared with cvs. IAC OL3 and IAC OL4 in 3 locations, in 2015/16

\begin{tabular}{|c|c|c|c|c|c|}
\hline \multirow{2}{*}{ Genotype } & \multicolumn{4}{|c|}{ Locations } & \multirow{2}{*}{ Index } \\
\hline & Pindorama & Ribeirão Preto & Votuporanga & Mean & \\
\hline IAC OL5 & 6,528 & 3,279 & 4,162 & 4,656 & 111 \\
\hline IAC OL3 & 5,790 & 3,132 & 4,340 & 4,421 & 103 \\
\hline IAC OL4 & 5,877 & 2,510 & 4,513 & 4,300 & 100 \\
\hline Mean & 6,025 & 2,973 & 4,338 & 4,445 & \\
\hline CV (\%) & 11.0 & 17.4 & 11.0 & 13.1 & \\
\hline
\end{tabular}

Table 4. Reactions of peanut cultivars to the virus TSWV (Tifton, GA, USA, 2015/2016)

\begin{tabular}{lcc}
\hline Cultivar & Disease Index & Resistance Score $^{2}$ \\
\hline Granoleico & 20.1 & $\mathrm{~S}$ \\
IAC OL3 & 17.7 & $\mathrm{~S}$ \\
Sun Oleic 97 & 17.3 & $\mathrm{~S}$ \\
IAC 886 & 13.9 & MS \\
IAC OL5 & 10.3 & MRMS \\
Tifguard & 1.0 & $\mathrm{R}$ \\
\hline
\end{tabular}

${ }^{1}$ Disease index of cv. Tifguard (Index=1,0), standard genotype for high resistance to TSWV

${ }^{2}$ Score scale based on the indices of cv. Tifguard: 1-4=R (Resistant); 4.1-8.0=MR (moderately resistant); 8.1-12.0=MR-MS (Moderately Resistant to Moderately Susceptible); 12.1-16.0=MS (Moderately Susceptible); 16.1-20.1=S (Susceptible). 


\section{TECHNOLOGICAL TRAITS}

Kernels of IAC OL5 are round-shaped, commercially classified as "runner" type for their size (mean weight of 100 kernels $=60$ to $70 \mathrm{~g}$ ), and have tan testa color. Their oil content is of $48-49 \%$, and they present the high oleic trait $(70-80 \%)$.

\section{Seed production}

IAC OL5 was registered in Registro Nacional de Cultivares (Ministry of Agriculture, Brazil) in 2016; IAC is the creator and maintainer of the cultivar, and produces the genetic (breeder's) seeds.

\section{ACKNOWLEDGEMENTS}

The authors thank the following peanut companies for the financial support to the IAC breeding program responsible for the development of the cultivar: Balsamo Indústria de Alimentos, Brumau Exportadora de Óleo e Grãos, CAP Agroindustrial Exportação, Cooperativa Camap, Cooperativa Copercana, Cooperativa Coplana, Manduca Produção de Sementes, Mars Brasil Indústria de Alimentos, MIAC Máquinas Agrícolas, Santa Helena Indústria de Alimentos, and Sementes Esperança.

\section{REFERENCES}

Godoy IJ, Carvalho CL, Martins ALM, Bolonhezi D, Freitas RS, Kasai FS, Ticelli M, Santos JF, Oliveira EJ and Morais LK (2009) IAC 503 e IAC 505: cultivares de amendoim com a característica "alto oleico". In Anais do $5^{\circ}$ Congresso Brasileiro de Melhoramento de Plantas. SBMP, Guaraparí (CD-ROM).

Godoy IJ, Santos JF, Carvalho CRL, Michelotto MD, Bolonhezi D, Freitas RS, Ticelli M, Finoto EL and Martins ALM (2014) IAC OL3 e IAC OL4: new Brazilian peanut cultivars with the high oleic trait. Crop Breeding and Applied Biotechnology 14: 200-203.

IEA - Instituto de Economia Agrícola (2016) Estatísticas da produção paulista/ amendoim. Available at < www.iea.sp.gov.br >. Accessed on November 11, 2016.

Mozingo RW, O'Keefe SF, Sanders TH and Hendrix KW (2004) Improving shelf life of roasted and salted inshell peanuts using high oleic fatty acid chemistry. Peanut Science 31: 40-45. 